\title{
PHALENA MACROURA.
}

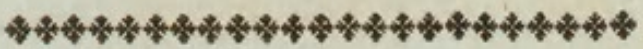

CharACTER GENERICUS.

Antenna setaceæ, a basi ad apicem sensim attenuatæ.

Ala (sedentis) sæpius deflexæ (volatu nocturno.)

Lin. Syst. Nat. p. 808.

CHARACTER SPECIFICUS, ${ }^{2} \mathrm{C}$.

PHALÆNA ferruginea, alis inferioribus caudatis longissimis.

Drury ins. 3. p. 39. t. 29.

Ex omnibus lepidopteris quæ hactenus physicis innotuerunt, nescio an non Phalæna macroura præcipue notatu digna sit ob enormem longitudinem appendicum, quasi in caudæ similitudinem excrescentium, quibus alæ inferiores terminantur. Africæ incola in phalænis rarioribus exoticis numeratur. In eleganti Domini Drurii opere censeo eam primo descriptam fuisse et depictam. 


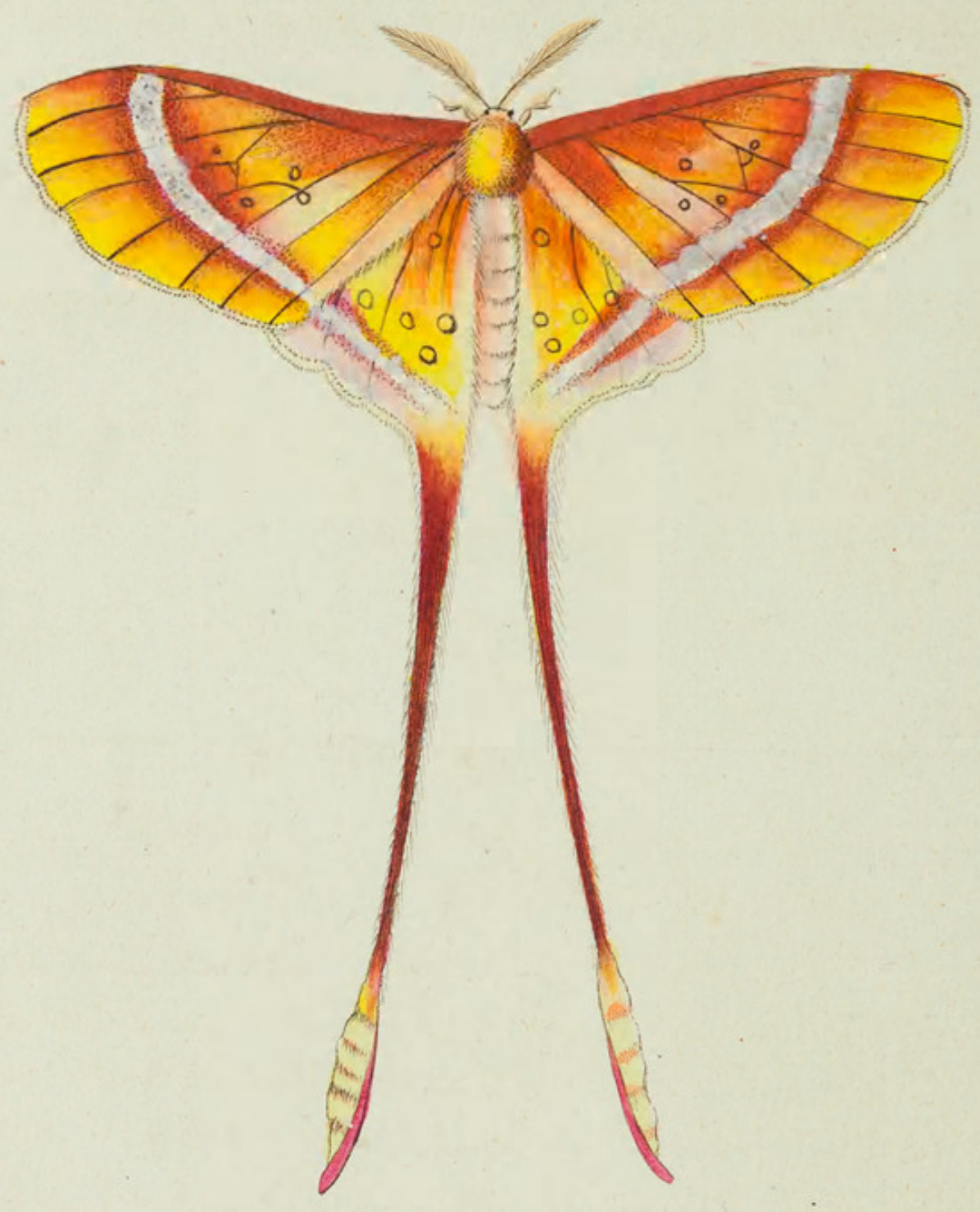

Rur 


\section{THE \\ LONG-TAILED PHALENA.}

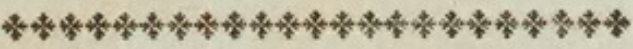 \\ GENERIC CHARACTER.}

Antennce setaceous, gradually lessening from the base to the tip.

Wings (when at rest) commonly deflected.

(flight nocturnal.)

$$
\text { SPECIFIC Character, छc. }
$$

Ferruginous PHAL ENA, with the lower wings extended into extremely long tail-like processes.

$$
\text { Drury ins. p. 39. pl. } 29 .
$$

Of all the lepidoptera yet known, the present species is perhaps the most remarkable for the excessive length of the tail-like processes or appendices with which the lower wings are terminated: it is a native of Africa, and is numbered among the rarest of the exotic Phalænæ. It seems to have been first described and figured in the elegant work of Mr. Drury. 


\section{$2 \mathrm{BHL}$ Biodiversity Heritage Library}

Shaw, George. 1801. "The Long-Tailed Phalæna, Phalæna macroura [PI. 520]." The Naturalist's Miscellany 13(CXLVI), https://doi.org/10.5962/p.310966.

View This Item Online: https://www.biodiversitylibrary.org/item/281546

DOI: https://doi.org/10.5962/p.310966

Permalink: https://www.biodiversitylibrary.org/partpdf/310966

\section{Holding Institution}

Museums Victoria

\section{Sponsored by}

Atlas of Living Australia

\section{Copyright \& Reuse}

Copyright Status: Public domain. The BHL considers that this work is no longer under copyright protection.

This document was created from content at the Biodiversity Heritage Library, the world's largest open access digital library for biodiversity literature and archives. Visit BHL at https://www.biodiversitylibrary.org. 